\title{
ANALYSIS OF TRACES AT ORNL'S NEW HIGH-FLUX NEUTRON ACTIVATION LABORATORY*
}

\author{
Enzo Ricci, T. H. Handley, and F. F. Dyer \\ Analytical Chemistry Division \\ Oak Ridge National Iaboratory
}

\section{ABSTRACT}

A new facility for neutron activation analysis (NAA) with a thermal flux of $5 \times 10^{14} \mathrm{~cm}^{-2} \mathrm{sec}^{-1}$ has recently been installed at the ORNL High Flux Isotope Reactor. This unusually high flux together with a small computer and necessary software for $\gamma$-ray spectrometry with a $\mathrm{Ge}\left(\mathrm{Li}_{i}\right)$ detector makes possible shorter irradiation, faster data analysis, and more economical analysis than is possible using more conventional facilities. We discuss features and tests of the new High-Flux NAA Laboratory, as well as results of comparator and absolute NAA of several types of environmental matrices for mersury, cadmium, bromine, arsenic, chlorine and sodium.

\section{NWW ANALYYTTCAL TRENDS AND THE NEW LABORATORY}

The present need in biomedical and environmental sciences is for determination of many trace elements in a variety of samples. Thus, one approach is to develop methods for multielement analysis at reasonable cost.** In such determinations, however, quality cannot be sacrificed for speed. Our aim is to develop techniques (preferably instrumental) for simultaneous analysis of numerous trace elements while concurrently reducing the price of quality serial analyses for specific elements by non-destructive methods. The new High-FIux NAA Laboratory can meet these demands. The very high thermal neutron flux permits determination of elements with extreme sensitivity, while also requiring shorter irradiations. Thus, a larger number of samples chal is trradiated than would be possible at a lower flux.

Figure 1 shows the new facility in detail; particularly, the pneumatic transfer system. Hot-sample handling cell and counting room are provided aiong.

* Research Sponsored by the U. S. Atomic Energy Commission under contract with Unicn Carbide Corporation.

*W. S. Lyon, E. Ricci, H. H. Ross, Analytical Chemistry 44, 438R (1972). 
With a computer-analyzer for pocessing spectra. We may transfer samples, automatically, to any of three stations: a sample-loading station shielded in a hot cell (No. 12, Fig. 1), an in-vessel irradiation station (No. 4), and an in-pool holding station (No. 8) to allow for preliminary decay of samples having high short-lived radioactivity. The in-vessel (irradiation) station, located in the reactor's beryllium neutron reflector (No. 3), is exposed to a thermal neutron flux of $5 \times 10^{14} \mathrm{~cm}^{-2} \mathrm{sec}^{-1}$ and to a resonance neutron flux of $1 \times 10^{13} \mathrm{~cm}^{-2} \mathrm{sec}^{-1}$. We may preset irradiation time so that the sample is automatically returned to either the loading or the holding station in approximately 3 seconds.

Because the irradiation station is in beryllium, the neutron flux gradient across the width of the rabbit is only $5 \%$, on the average, as illustrated by Table $I$. This makes possible accurate analyses without detailed attention to the placement of samples in the capsules. For greater accuracy the rabbits can rotate during irradiation, in which case the flux gradient would be only $2.5 \%$ from outside to center. We have not found any measurable gradient along the capsule axis (Table I). The beryllium moderator also causes enhancement of the thermal to resonance flux ratio ( $\sim 50)$, so that resonance activation is minimized, and absolute activation analysis accurately performed. Interfering fast-neutron products are also reduced.

Air columns stop the rabbits at both the loading and the in-vessel stations; we can thus irradiate fragile capsules without breakage. Because the very high neutron and gamma fluxes ( 6 watt/g) in this facility cause excessive radiation damage to polyethylene rabits, their use is limited to irradiations of up to 30 minutes. We use capsules made of high-purity graphite and magnesium (both fragile) for Ionger irradiations and/or to prevent excessive heating of samples. Polyethylene and graphite activate very little, and only $27 \mathrm{Mg}(9.5 \mathrm{~min}$.) is significantly induced in the magnesium capsules.

The counting-computing complex uses a Ge(Ii) detector with $12 \%$ relative efficiency $\left(75 \mathrm{~cm}^{3}\right)$, and a Nuclear Data $50 / 50$ system, consisting of a 4096-word (24 bit) analyzer and a 8192-word (18 bit) PDP-15 conputer with two readers for magnetic tape and one for paper tape. Presently, the software used to process gamma spectra consists of 17 subroutines divided into 9 relocatable overlays. The most important routines are:

\section{NOTICE}

This report was prepared as an account of work sponsored by the United States Government, Neither the United Stales nor the United States Atomic Energy Cominission, nor any of their employees, nor iny of their contractorn, subcontractors, or thoir employees,
mekes any warranty, oxpreas or impliod, or auumet any iegal linbility or sesponsibility for the accuracy, completeness or usefuiness of any information, apparatui; 
CALIB: Sets energy and counting efficiency scales for Ge(Ii) spectra. Determines thermal and resonance neutron fiux, from activation of gold and manganese monitors, by solving system of two equations.

NETPK: Searches spectra for peaks; computes energies, count-rates (total area minus base-line), photon-ermission rates and corresponding statistical errors.

MULT: Finds peak multiplets (up to 5 components) and computes individual peak parameters (as NETPK).

SMPDPS: Computes (a) comparator activation analysis results from NETPK rates; (b) disintegration rates, by using NITPK rates and radioisotope nuclear data from a master tape; (c) absolute activation analysis results from disintegration rates and flux data (from CALIB).

IIM: Computes analytical limits of detection (basis: 3.5 stanaard deviaitions over background).

\section{RESULTS AND DISCUSSION}

Comparator Activation Analysis

Due to the importance of mercury in environmental studies, we analyzed a number of samples -- some of them N.B.S. standards and round-robin specimens -- nondestructively for mercury at the High Flux NAA Laboratory. Table II compares these results with those obtained either by other techniques or by conventional NAA methods. In some of the latter, mercury was separated radiochemically by first leaching samples with a nitric-sulfuric acid mixture and then precipitating mercuric sulfide for counting.

Most of the data show satisfactory agreement with those obtained by other methods, even at the lower ranges of concentration. The results for the Allen Steam Plant coal, however, show a serious positive systematic error. We liat them to point out a pitfall encountered in NAA for mercury by counting 65-hr ${ }^{197} 7_{\mathrm{Hg}}$ with the $\mathrm{Ge}(\mathrm{II})$ detector. Rare-earth radionuclides formed in these samples by irradiation emtt $x$-rays of various energies .- the $105 \mathrm{KeV}$ photon of $155 \mathrm{Sm}$ is very intense. These $\mathrm{x}$-rays excite the $\mathrm{K}$ absorption edge ( $80.7 \mathrm{KeV}$ ) in the gold lining on the face of the $G e(I, i)$ detector. The resulting fluoresence interferes seriously with the counting of the ${ }^{197} \mathrm{Hg}$ radiations - - particularly that of $77 \mathrm{KeV} \mathrm{-.} \mathrm{since} \mathrm{these} \mathrm{are} \mathrm{all} \mathrm{gold} \mathrm{x-rays.} \mathrm{We} \mathrm{solved} \mathrm{this} \mathrm{pro-}$ blem by using the standara adaition technique on the other samples, as Table II shows. 
Mercury loss under irradiation is a serious problem in NAA, and was of concern to us in our facility, since we have a relatively high rate of gama heating. Table III shows the effects of increasing?y longer irradiations on known amounts of solutions of mercury nitrate, dr ied into irradiation capsules. No loss is observed during irradiations o. up to 12 minutes in the High Flux NAA Laboratory. Our bombardments of mercury samples never exceeded 6 minutes.

We have also made some preliminary determinations 11 cadmium in the Allen Steam Plant samples. Contrary to statements that NAA $i_{i}$ insensitive for this element, our results show that the method is feasible -- even without chemistry-down to I ppm at the High-FIux ITAA Laboratory.

Ecologists are concerned about transport of arsenic from sprayed plants, by insects. Grasshoppers were exposed for several days to water contaminated with arsenical insecticides. We later analyzed these insects for arsenic

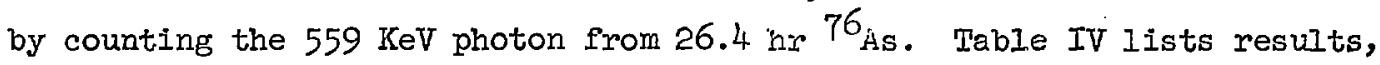
which generally correspond to the increasing amounts of poisoiling. Most analyses were nondestructive; we counted after sufficient decay of interference $24 \mathrm{Na}(15.0 \mathrm{hr})$. The determinations corresporsing to 0.015 and 0.15 ppm arsenic water levels required. chemical separations, hovever. Here we dissolved the dried (or ashed) grasshoppers in nitric acid, aded sodium bromide, bolled off the interfering bromine ( 2 or 3 times), and precipitated arsenic sulfide with thioacetamide for counting. Ire errors (Table IV) are acceptable throughout the range of concentrations founa $(0.48-903 \mathrm{ppm})$.

Absolute Activation Analysis

We have just begun to study environmental multielement baselines of pristine regions, and contamination levels of more polluted areas. Table $V$ gives results for four background elements in clean samples of Whatman No. 42 air: filter paper. We obtained the necessary thermal and resonance flux data by simultaneous bombardment of aluminun-diluted manganese $\left(\sigma_{0}=13.3 \mathrm{i}, I_{0}=\right.$ $15.6 \mathrm{~b})$ and gold $\left(\sigma_{0}=98.8 \mathrm{~b}, I_{0}=1558 \mathrm{~b}\right)$ monitors, and by using the CALIB subroutine at the PDP-15 computer. The table also shows satisfactory results of an accuracy test of the absolute activation analysis subroutines (IFTPK and 
SMPDPS) for which known concentrations of manganese and gold in aluminum (monitors) were redetermined. Clearly, the preliminary detection limits listed (subroutine IIM) can be easily improved and the number of elements increased, by adequate $c$ rabination of irradiation and decay times.

Having proved the us efulness of the new High-FIux NAA Laboratory for serial quality trace anal sis by the comparator method, we are now developing the absolute $t \in$ shnique for multielement analysis. Both efforts are directed toward solution of environmental type problems. 
TABIE I

FIUX GRADIEINT ACROSS HFIR CAPSULE RY TANTALUM ACTTVATION

\begin{tabular}{|c|c|c|c|c|c|c|c|}
\hline $\begin{array}{l}\text { Tantalum } \\
\text { Wire } \\
\text { Position }\end{array}$ & $\begin{array}{l}\text { EXPERIN } \\
\text { Spe :ific } \\
\text { Act vityc }\end{array}$ & $\begin{array}{l}\text { ENT } \#_{1} \\
\text { Deviation }\end{array}$ & $\begin{array}{l}\text { EXPERIM } \\
\text { Specific } \\
\text { Activityc }\end{array}$ & $\begin{array}{l}\text { GNI \#2 } \\
\text { Deviation }\end{array}$ & $\begin{array}{l}\text { FXPERII } \\
\text { Specific } \\
\text { Activityc }\end{array}$ & $\begin{array}{l}\text { INT } \frac{14}{17} \\
\text { Deviation }\end{array}$ & $\begin{array}{l}E \\
\text { Speci } \\
\text { Activ }\end{array}$ \\
\hline & cps/ 3 & $\%$ & cps/g & $\%$ & $\mathrm{cps} / \mathrm{g}$ & $\%$ & cps/ \\
\hline \multicolumn{8}{|l|}{ WIDIH: ${ }^{a}$} \\
\hline$I$ & 2210 & 0 & 9278 & 0 & 11888 & 0 & 9110 \\
\hline 2 & 2276 & 3.0 & 9481 & 2.2 & 1.2072 & 1.6 & 9276 \\
\hline 3 & 2311 & 4.6 & 9641 & 3.9 & 12352 & $3 \cdot 9$ & 9481 \\
\hline 4 & 2301 & 4.1 & 9712 & 4.7 & 12508 & 5.2 & 9642 \\
\hline 5 & 2217 & 0.32 & 9536 & 2.8 & 12256 & $3 \cdot 1$ & 9353 \\
\hline 6 & 2231 & 0.95 & 9402 & 1.3 & 11958 & 0.59 & 9254 \\
\hline
\end{tabular}

LENGTH :

$\begin{array}{ccccc}\text { Top } & 3851 & 0 & 3499 & 0 \\ \text { Bottom } & 3796 & -1.4 & 3544 & 1.3\end{array}$

A Around (cylindrical) vbbit circumference, clockwise. bix Ta wires were placed verticall parallel, around the nside circumference of rabbit. bcross rabbit length. cFrom $18 \mathrm{I}_{\mathrm{T}}$ II2d.; sum of 1221 ani $1121 \mathrm{KeV}$ peaks after $\mathrm{Ge}\left(\mathrm{II}_{\mathrm{i}}\right.$ counting. Nornialized to equal decay. error $0.3 \%$. 
TABLE I

FLUX GRADIEIT ACROSS HFIR CAPSUTE BY TANTALUM ACTIVATION

\begin{tabular}{|c|c|c|c|c|c|c|c|}
\hline \multicolumn{2}{|c|}{$\begin{array}{l}\text { EXPERIMEINT \#I } \\
\text { Spe :ific }\end{array}$} & \multicolumn{2}{|c|}{ EXPERIMENT \#2 } & \multicolumn{2}{|c|}{ EXPERIMENT \#3 } & \multicolumn{2}{|c|}{ 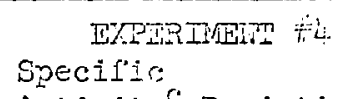 } \\
\hline cps/ 5 & $\%$ & $\mathrm{cps} / \mathrm{g}$ & $\%$ & $\mathrm{cps} / \mathrm{g}$ & $\%$ & $\mathrm{cps} / \mathrm{s}$ & $\%$ \\
\hline 2210 & 0 & 9278 & 0 & 1.2888 & 0 & 9110 & 0 \\
\hline 2276 & 3.0 & 9481 & 2.2 & 12072 & 1.6 & 9276 & I. 8 \\
\hline 2311 & 4.6 & 9641 & 3.9 & 12352 & 3.9 & 9481 & 4.1 \\
\hline 2301 & 4.1 & 9712 & 4.7 & 12508 & 5.2 & 9642 & 5.8 \\
\hline 2217 & 0.32 & 9536 & 2.8 & 12256 & 3.1 & 9353 & 2.7 \\
\hline 2231 & 0.95 & 9402 & 1.3 & 11958 & 0.59 & 9254 & 1.6 \\
\hline
\end{tabular}

3851

$\begin{array}{ccc}0 & 3499 & 0 \\ -1.4 & 3544 & 1.3\end{array}$

ylindrical) abbit circumference, cloclwwise. Six Ta wires were placed vertickally and around the nside circumference of rabbit. $b_{\text {Across rabbit length. }}{ }^{c_{F r o m}}{ }^{1} 8_{\mathrm{Ta}}(n, y)^{182_{\mathrm{Te}}}$ m of $122 \mathrm{I}$ anc II2I KeV peaks after $\mathrm{Ge}(\mathrm{Li})$ counting. Normalized to equal decay. Co/nting \%. 
TABLE II

COMPARISON OF MERCURY DEITERMINATIONS AT THE

HIGH-FLUX NAA IAB. WIIH THOSE BY OTHER NETHODS

\begin{tabular}{|c|c|c|c|c|c|c|}
\hline \multirow[b]{3}{*}{ Series } & \multirow[b]{3}{*}{ Sample } & \multirow{3}{*}{$\begin{array}{c}\text { Mass } \\
\text { Spectrometry }\end{array}$} & \multirow{3}{*}{$\begin{array}{l}\text { Atomic } \\
\text { Absorption }\end{array}$} & \multicolumn{3}{|c|}{ Neutron Activation Analys is } \\
\hline & & & & \multirow{2}{*}{$\begin{array}{c}\text { High-FIux } \\
\text { NAA Lab. } \\
\text { (Nondestructive) }\end{array}$} & \multicolumn{2}{|c|}{$\begin{array}{c}\text { Conventional, with } \\
\text { NaI (TI) }\end{array}$} \\
\hline & & & & & Chem. Sep. & Nondestructive \\
\hline & No. & ppm & ppm & ppm & ppm & ppm \\
\hline Round Robin & $\begin{array}{l}\text { Sediment: } \\
\text { r2C5643 } \\
72 \mathrm{C} 5644 \\
7265645\end{array}$ & & $\begin{array}{l}113-110 \\
42.9-43.9 \\
.089-.056\end{array}$ & $\begin{array}{l}100-101 \\
38.6-38.7 \\
<1-<1\end{array}$ & $\begin{array}{l}135-115 \\
47.0-46.6 \\
.05-.06\end{array}$ & $\begin{array}{c}143-128 \\
49-43\end{array}$ \\
\hline N.B.S. Standards & Orchard Leaves & $.12-.13$ & $.12-.13$ & .167 & .158 & \\
\hline & Coal & & & .106 & .305 & \\
\hline Allen Steam Plant & $\begin{array}{c}\text { Coal: } \\
\text { A } \\
B \\
\text { C } \\
\text { D }\end{array}$ & & $\begin{array}{l}.064 \\
.069 \\
.076 \\
.060\end{array}$ & $\begin{array}{l}.18 \\
.19 \\
.32 \\
.26\end{array}$ & $\begin{array}{l}.060 \\
.049\end{array}$ & \\
\hline Alien Steam Plant & $\begin{array}{l}\text { Slag: } \\
\text { E(Solid) } \\
F(\text { Water }) \\
\text { G(Solid) }\end{array}$ & & .001 & $\begin{array}{l}.09 \\
\text { n.à. } \\
.07\end{array}$ & & \\
\hline
\end{tabular}

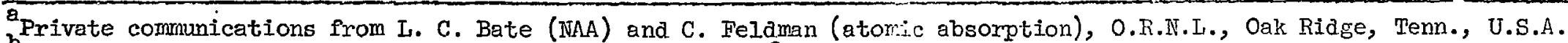

b.B.S. Values: Orchard Leaves $.155 \mathrm{ppm}$; Coal .13 ppm. These results have large systematic error due to interfering $x$-ray fluorescence from detector (see text). 
TABTE III

INFLUENCE OF HFIR IRRADIATION LENGTH

ON MERCURY IOSS (MAGNESIUN RABBIT)

\begin{tabular}{|c|c|c|c|}
\hline $\begin{array}{l}\text { Irradiation } \\
\text { Length }\end{array}$ & $\begin{array}{l}\text { Amount } \\
\text { Hg used }\end{array}$ & $\begin{array}{l}\text { Specific } \\
\text { Activity }\end{array}$ & $\begin{array}{l}\text { Deviation } \\
\text { (rron avge. } \\
4 \text { min.) }\end{array}$ \\
\hline min. & $\mu g$ & cps/ug & $g_{0}^{\prime}$ \\
\hline 1 & & 251 & -3.6 \\
\hline 2 & & 254 & -2.5 \\
\hline 3 & & 252 & $-3 \cdot 3$ \\
\hline 4 & & 262 & 0.58 \\
\hline $4^{b}$ & 19.9 & 259 & -0.58 \\
\hline 4 & 6.74 & 265 & 1.7 \\
\hline 6 & $7 \cdot 32$ & 259 & -0.58 \\
\hline 12 & $7 \cdot 33$ & 259 & -0.58 \\
\hline 18 & 7.20 & 221 & -15.2 \\
\hline 18 & 6.92 & 205 & -21.3 \\
\hline
\end{tabular}

$a_{\text {From }}{ }^{202} \mathrm{Hg}(n, \gamma)^{203_{H g}} 45.8 \mathrm{~d}$; normalized to I min. irradiation and to equal decay, after $\mathrm{Ge}(\mathrm{Li})$ counting of $279 \mathrm{KeV}$ peak. Counting error $1 \%$. b Start of secona experiment series; average of this result with 4-min result of first series is basis for deviation \% calculation. 
TABLE IV

As DETERMTINATION LNV GRASSHOPITIRS

SUBJECTRD TO ARSENICAL DIETS

\begin{tabular}{lccccc}
\hline $\begin{array}{l}\text { Arsenical } \\
\text { Used }\end{array}$ & $\begin{array}{c}\text { As Level } \\
\text { In Water } \\
\text { Feed }\end{array}$ & \multicolumn{2}{c}{$\begin{array}{c}\text { As Concentration } \\
\text { In Grasshoppers }\end{array}$} & $\begin{array}{c}\text { Counting } \\
\text { Ist Set 2nd Set }\end{array}$ & Error \\
\hline & ppm & ppm & ppm & $\%$ \\
\hline $\mathrm{A}_{2} \mathrm{O}_{3}$ & 0.015 & 0.48 & 0.48 & 6.3 \\
& 0.15 & 1.6 & 0.69 & 1.4 \\
& 1.50 & 6.2 & 5.1 & 5.9 \\
& 15.0 & 65.3 & 60.4 & 6.8 \\
& 150 & 97.6 & 158 & 8.7 \\
$\mathrm{~A}_{2} \mathrm{O}_{5}$ & 0.15 & 2.3 & & \\
& 15.0 & 33.8 & 65.3 & 13.3 \\
& 150 & 107 & 101 & 8.1 \\
& 1500 & 164 & 374 & 2.6
\end{tabular}

\begin{tabular}{ccccc} 
Cacodylic & 1.50 & & & \\
Acid & 15.0 & 75.4 & $(21)$ & $(45)$ \\
& 150 & 97.9 & 285 & 4.5 \\
& 1500 & 78.7 & 472 & 2.4 \\
& $"$ & 429 & & \\
& $"$ & 903 & & \\
& $"$ & 458 & & \\
Phytar & 15000 & & 437 & 2.3 \\
& 0.15 & 3.5 & & \\
& 15.0 & 16.6 & $(5.2)$ & $(40)$ \\
& 150 & 330 & 150 & 5.9 \\
& 1500 & 769 & 600 & 1.4 \\
\hline
\end{tabular}

${ }^{\text {a }}$ only for 2na. set of grasshopper samples. 
TABIE V

PREITMTNARI ABSOUUTY MAA RESULIS

\begin{tabular}{|c|c|c|c|c|c|c|c|c|}
\hline \multirow[t]{2}{*}{ ilement } & \multicolumn{2}{|c|}{ Measured Product } & \multicolumn{2}{|c|}{$\begin{array}{l}\text { Analysis of } \\
\text { Whatunino. } 42 \\
\text { Ain Filter Eapea }\end{array}$} & \multicolumn{2}{|c|}{$\begin{array}{c}\text { Test of Absolute } \\
\text { Activation Analysis } \\
\text { ifethod }\end{array}$} & \multirow[t]{2}{*}{ Error } & \multirow{2}{*}{$\begin{array}{l}\text { Corresponding } \\
\text { Detection } \\
\text { Iimits } \\
\text { (p.p.r.) }\end{array}$} \\
\hline & Irucitide & $\begin{array}{c}\text { Falf-Ijit } \\
(h r .)\end{array}$ & $\begin{array}{l}\text { SampIe } 1 \\
(p . p \cdot m .)\end{array}$ & $\begin{array}{l}\text { Semple? } \\
\left(p . p . m_{0}\right)\end{array}$ & $\begin{array}{c}\text { Found } \\
(\%)\end{array}$ & 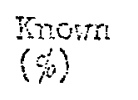 & & \\
\hline $\mathrm{ME}$ & 24 ira & 15.0 & 16.8 & 16.8 & & & $0.7-0.6$ & 0.09 \\
\hline 02 & 38,1 & 0.62 & 291 & 282 & & & $2.2-2.7$ & 3.1 \\
\hline Mi & 56 & 2.58 & 0.27 & 0.26 & $0.08 \%$ & 0.097 & $0.9-3.00$ & 0.002 \\
\hline $\mathrm{Bn}$ & 82 & 35.3 & 0.24 & 0.22 & & & $\because 2 \cdots: 3$ & 0.009 \\
\hline$A \dot{u}$ & $198 \mathrm{Az}$ & 64.8 & & & $0.10 \mathrm{~s}$ & 0.109 & 0 & \\
\hline
\end{tabular}

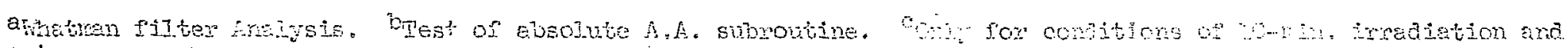
$3-4 \ln$. deate 


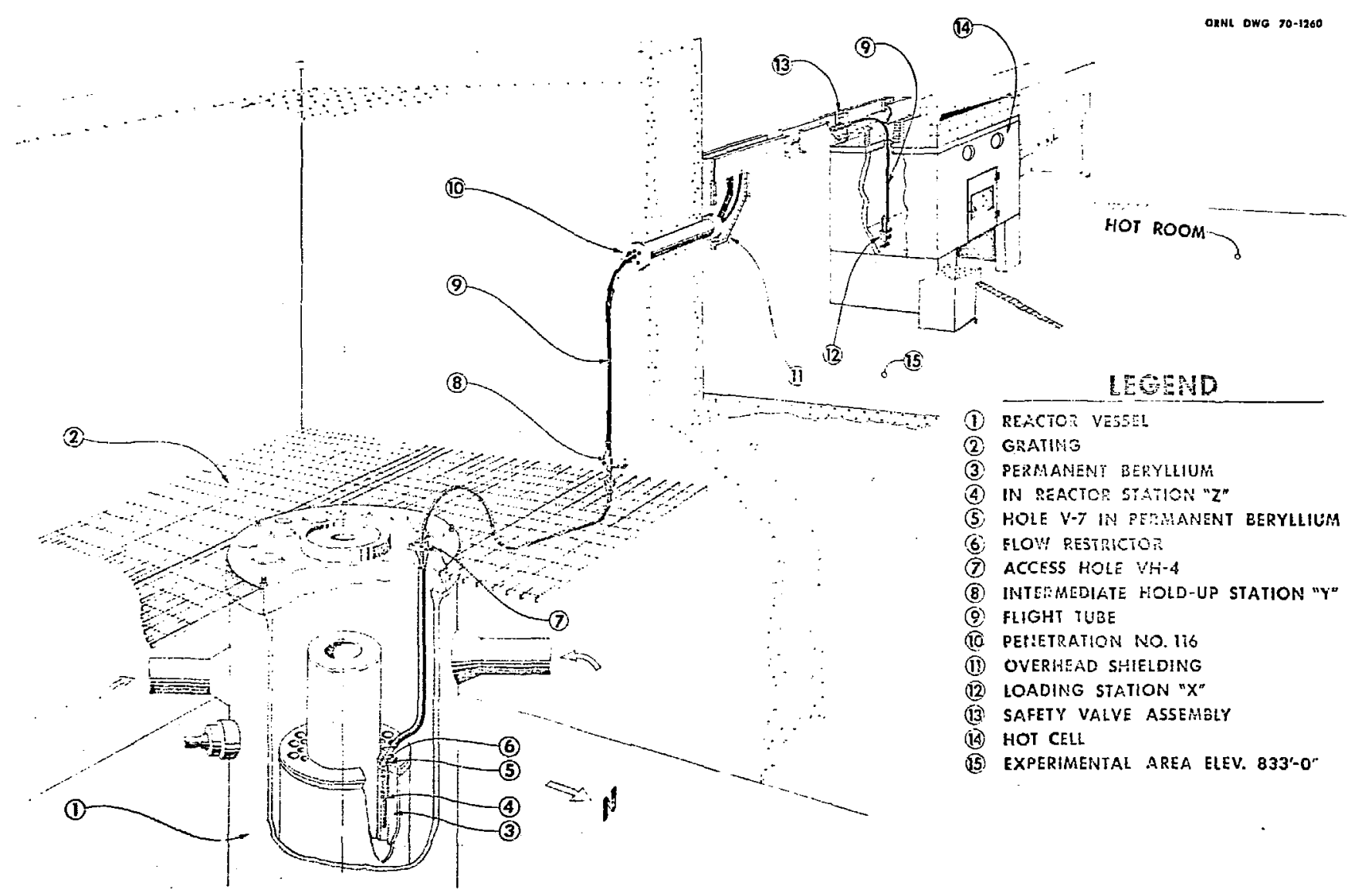

